
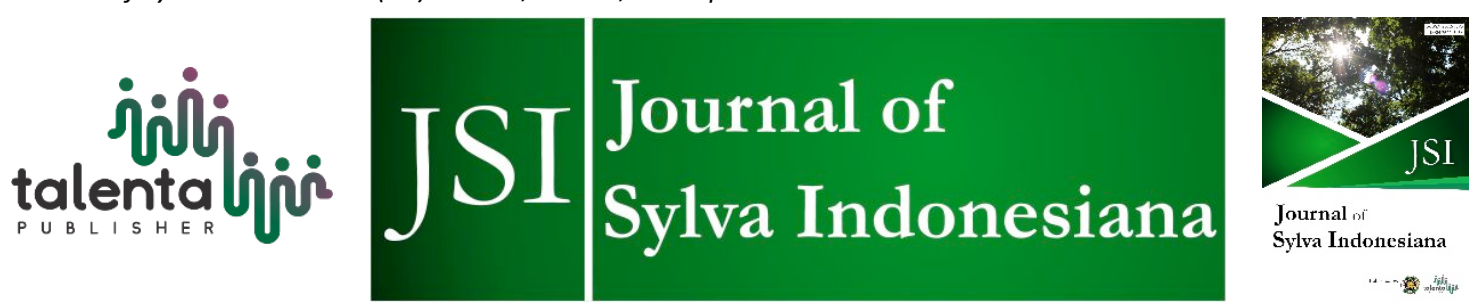

\title{
Utilization of Unmanned Aerial Vehicle (UAV) Technology for Mapping Mangrove Ecosystem
}

\author{
Ayub Sugara $^{1 *}$, Feri Nugroho ${ }^{2}$, An Nisa Nurul Suci $^{3}$, and Ari Anggoro ${ }^{1}$ \\ ${ }^{I}$ Department of Marine Science, Faculty of Agriculture, University of Bengkulu, Bengkulu, Indonesia \\ ${ }^{2}$ Department of Digital Business, Faculty of Economics and Business, Jakarta Global University, Jakarta \\ Indonesia \\ ${ }^{3}$ Department of Marine Science and Technology, IPB University, Bogor, Indonesia
}

\begin{abstract}
Traditional techniques of monitoring mangrove ecosystems are complex. Unmanned Aerial Vehicles (UAVs) are one form of remote sensing technique that could be useful for this purpose. The aim of this research is to mapping the mangrove ecosystem to collect spatial information and identify mangrove species through UAV technology. The mangrove data was taken in four stations in Lancang Utara Island, comprising marking, tracking, and aerial photo data collection using drone flights. The mangroves condition in the research location classified into good condition which the total area $37,184 \mathrm{~m}^{2}$. Rhizophora mucronata and Rhizophora stylosa are widely distributed in this location. The mangrove distribution revealed dense mangroves near the land and patchy mangroves farther away from the land. However, the mangrove ecosystem is surrounded by a lot of waste, particularly inorganic waste in the form of plastic. The plastics covered the mangrove roots which can cause stress and mortality. The use of UAV technology integrated with GIS to map mangrove ecosystems is expected to be a feasible alternative for extracting mangrove databases for future coastal ecosystem management.
\end{abstract}

Keyword: GIS, Mangrove, Remote Sensing, Rhizophora mucronata, Unmanned Aerial Vehicle

Received 19 April 2021 | Revised 21 May 2021 | Accepted 25 May 2021

\section{Introduction}

The coastal area is an ecosystem area that undergoes quite dynamic changes. These changes will affect changes in the surrounding ecosystem. The main ecosystems in Indonesia's coastal areas include mangrove forests, sea-grass beds, estuaries, coral reefs, and seaweed. In Indonesia, one of the areas experiencing coastal changes is the northern coast of Java (PANTURA) [1]. Mangroves are very productive ecosystems in coastal areas, and they're also highly vulnerable to external disturbances [3]. This is because the mangrove ecosystem is heavily influenced by

\footnotetext{
*Corresponding author at: Department of Marine Science, Faculty of Agriculture, University of Bengkulu, Jl. W.R Supratman Kandang Limun, Bengkulu 38371, Indonesia

E-mail address: ayubsugara@unib.ac.id

Published by Talenta Publisher, p-ISSN: 2622-5093 e-ISSN: 2622-5158 DOI: 10.32734/jsi.v4i02.6149

Journal Homepage: http://jsi.usu.ac.id
} 
natural factors such as tides, salinity, soil conditions, intake of organic and inorganic materials. Mangroves have many functions, including reducing waves, abrasion and intrusion, habitat for various species, and sources of human needs [4].

Remote sensing technology and Geographic Information Systems (GIS) are currently developing quite rapidly [5]. Both of these technologies can be used to determine the current condition of the coastal ecosystem. One of the methods used to obtain these images is to use an Unmanned Aerial Vehicle (UAV) or commonly known as a drone. UAV is a vehicle equipped with a flight control system through the Ground Positioning System (GPS) precision wave and control electronics so that it can fly according to the flight plan made by the UAV pilot. It makes UAV able to obtain high-resolution spatial data [6]. Aerial photography technology uses drones that are supported by special software that can be used for an area. High-resolution aerial photography provides many advantages because it can help survey activities in difficult areas [7]. Drone can also be a vehicle for field data collection in mapping shallow-water benthic habitats [8]. In addition, the use of drones can also be applied for mapping coral reefs, sea-grass, and observing sea turtles [9]-[11].

This study aims to determine the total area and spatial distribution of the mangrove ecosystem using UAV technology and also indentify the existance mangrove species in the North of Lancang Island, Seribu Islands. The application of UAV technology that is integrated with GIS in mangrove ecosystem mapping is expected to be an alternative in collecting mangrove databases for the management of coastal ecosystems, especially mangroves.

\section{Research Method}

\subsection{Area Study}

The research was conducted in the Lancang Utara Island, Seribu Islands, Jakarta (Figure 1). Field surveys and data collection were carried out at four stations. Tagging and tracking is done using a Garmin 78S GPS and one drone for aerial photo capture.

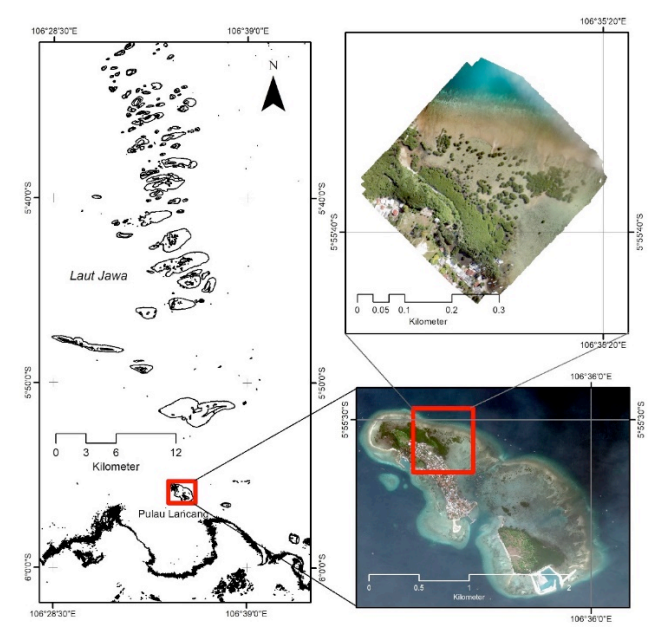

Figure 1 Area Study 


\subsection{Research Method}

The research method used is the survey methods, the research flow chart can be seen in Figure 2 below.

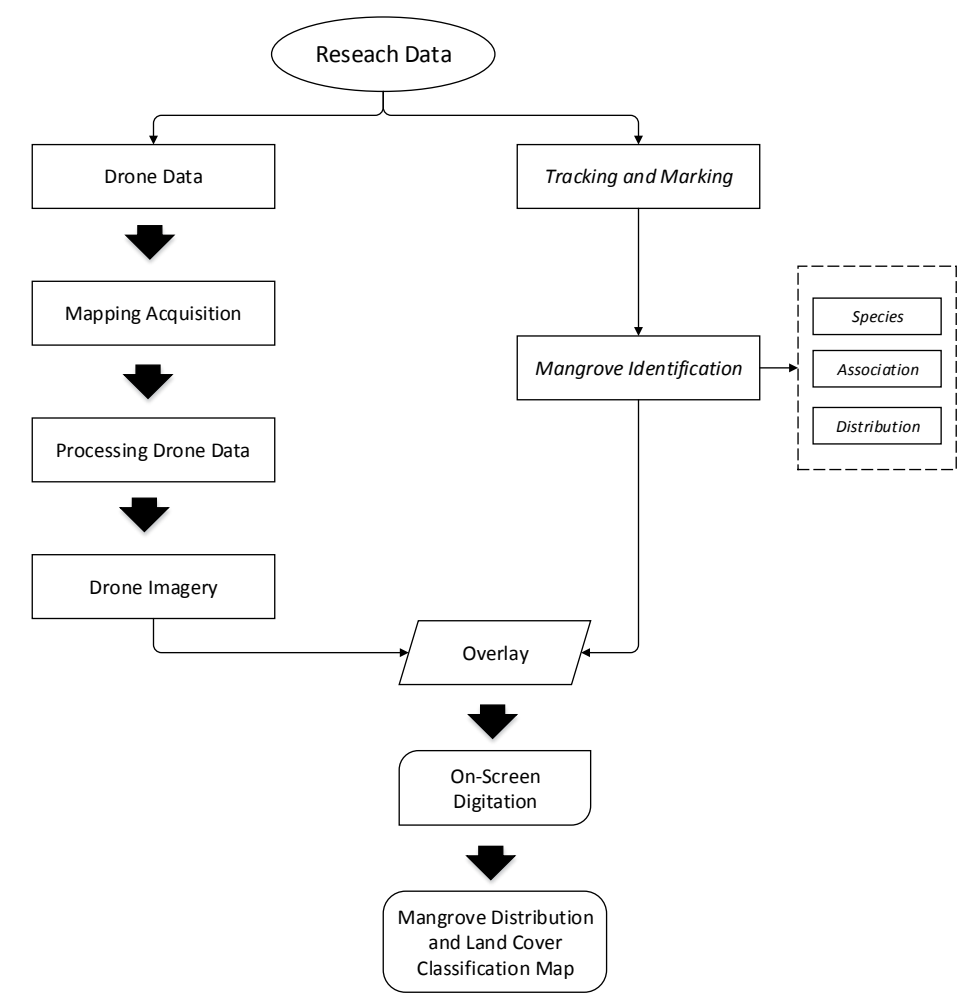

Figure 2 Research Flowchart

\section{A. Tools}

The tools used in this study were the DJI Mavic Pro type drone used for aerial photo data retrieval, the Xiaomi 5 Plus brand cellphone as a monitor for mapping using drones, GPS Garmin $78 \mathrm{~S}$ was used for tracking and marking mangrove areas, and cameras were used for documentation research activities. Meanwhile, the tools used to recapitulate findings about the status of the mangrove ecosystem were newtop paper and pencils.

\section{B. $\quad$ Method}

The mangrove survey was carried out by observing aerial photos using drones, tracking and marking the mangrove area - the use of drones as a vehicle for taking aerial photo data for mapping the distribution of mangroves. Before taking the aerial photo data, a camera was setup and a flight plan was made (Figure 3). The drone camera setup uses the DJI GO 4 software downloaded on the Play Store on Android. Drone camera setup is essential to ensure a good ISO range when performing flight missions. The settings in the aerial photo data collection technique are carried out with the help of the Pix4D Capture software integrated with Android. In this software, it can be seen that the satellite responds, the speed of drone when taking data, the estimated time and area of mapping. Aerial photo data collection in this study was carried out at 
an altitude of 80 meters, $80 \%$ overlapping for 12 minutes with an estimated mapping area of about 8 hectares.

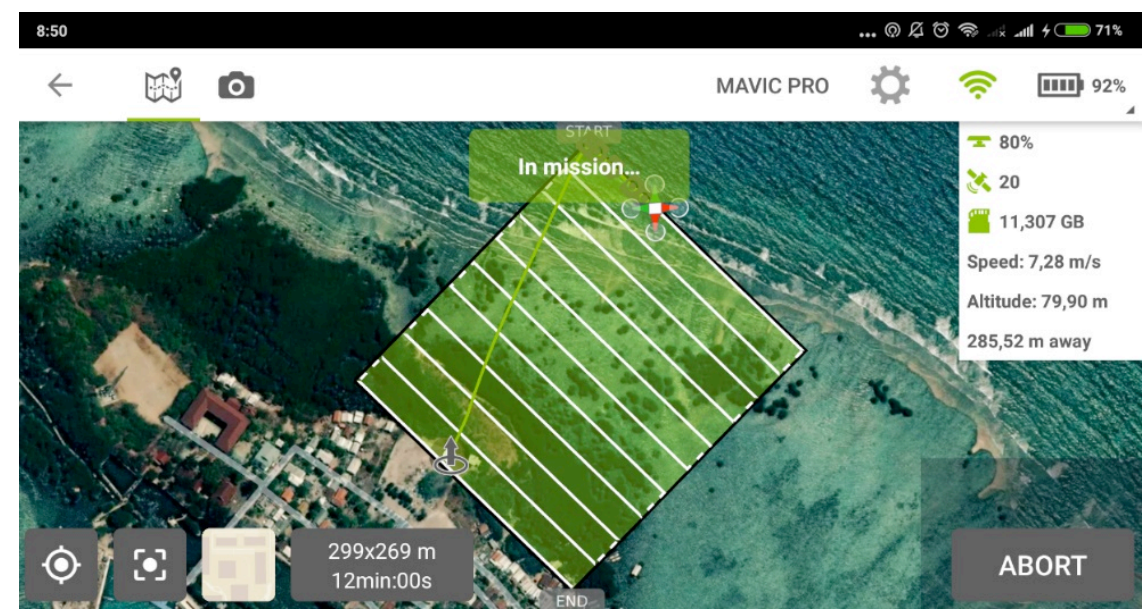

Figure 3 Capture Drone Flyway Plan In Pix4D Capture

The mangrove survey was carried out by tracking and marking using GPS Garmin 78S, besides identifying mangrove species, associations and distribution of mangroves. Tracking and tagging mangrove areas was carried out to collect relevant information about species, associations, and distribution. Meanwhile, data collection using drones was intended to collect aerial photo data, which will then be processed into orthomosaic of drone images. Then the mangrove identification data is overlaid onto the orthomosaic of drone image as a result of aerial photo processing. Furthermore, on-screen digitization is carried out based on drone image data and field surveys contextual. Data analysis was carried out on drone images to produce maps of mangrove distribution and land cover.

\section{Results and Discussion}

The mangroves in Lancang Utara Island condition presented in Figure 4. Based on figure 2, the condition of the mangroves in the study area is classified as dense because there is no illegal logging. However, at that location, there is a lot of plastic waste that will disrupt the condition of the ecosystem. The presence of waste can cover the pneumatophores of mangrove roots so that it can affect respiration and cause death in mangroves [12]. The plastic waste can also causes excessive growth of pneumatophores and increase leaves fall due to stress which over time will cause death in mangroves [13]. In addition, the presence of inorganic waste can reduce the fertility level of the soil in mangroves, which can affect the growth rate and sustainability of mangroves. Based on the ecological aspect, mangrove mortality can disrupt the population of various types of biota that are associated in the mangrove ecosystem [14]. Figures $4 \mathrm{a}$ and $\mathrm{b}$ are taken on the inner side of mangrove ecosystem, while in Figure $4 \mathrm{c}$ and d are taken on the outer side of mangrove ecosystem bordering a shallow water area. Mangrove roots bordering shallow waters serve as shelter for inorganic waste such as plastics, so that plastic does not enter the land 
around residential areas. The type of mangrove found at the research location was Rhizophora mucronata. It is known that the mangrove species Rhizophora mucronata ecologically have the same growing location with Rhizophora apiculata but are more tolerant of harder substrates and sand [15].
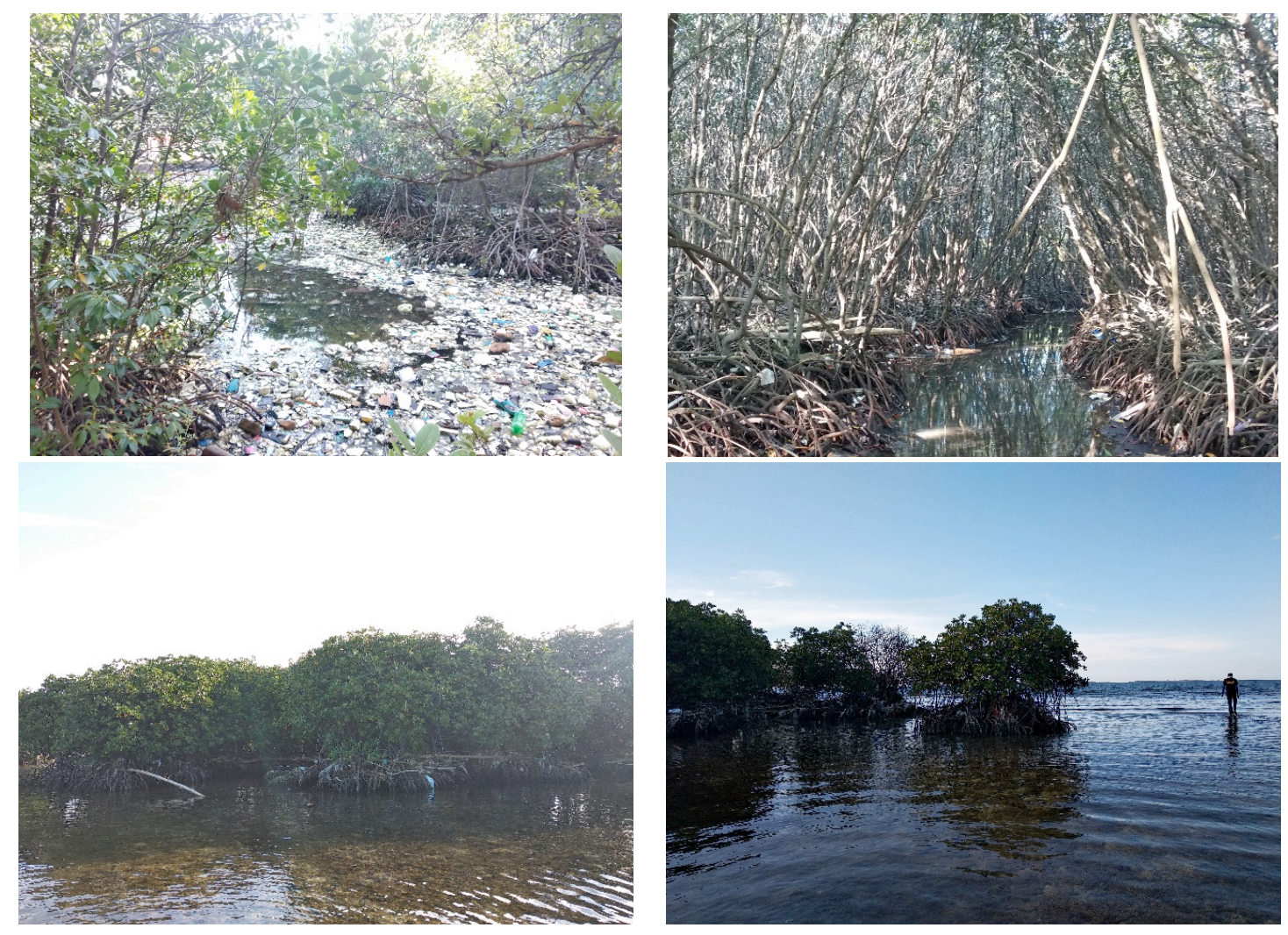

Figure 4 Mangrove condition

\subsection{Mangrove in Lancang Island}

Based on drone image processing, the mangroves in Lancang Island cover an area of 37,184 $\mathrm{m}^{2}$ site. The mangrove distribution is shown in Figure 5. The mangrove coverage classified into dense in the side that nearby the land and patchy in the side that far from the land. Lancang Island's mangrove area is a rehabilitation area. Mangroves are only planted on the side of the island closest to the mainland. The mangrove cover on the mainland side becomes dense as a result of this. Mangroves that have been planted produce propagules. Some propagules are conveyed by water and growth in locations that are further away from land.

The mangrove ecosystem in the North of Lancang Island consists of Rhizophora mucronata and Rhizophora stylosa. These two species of mangrove are the common species that are oftenly planted for rehabilitation purpose in Indonesia [16] due to easy to grow and have a wide range distribution [17]. 


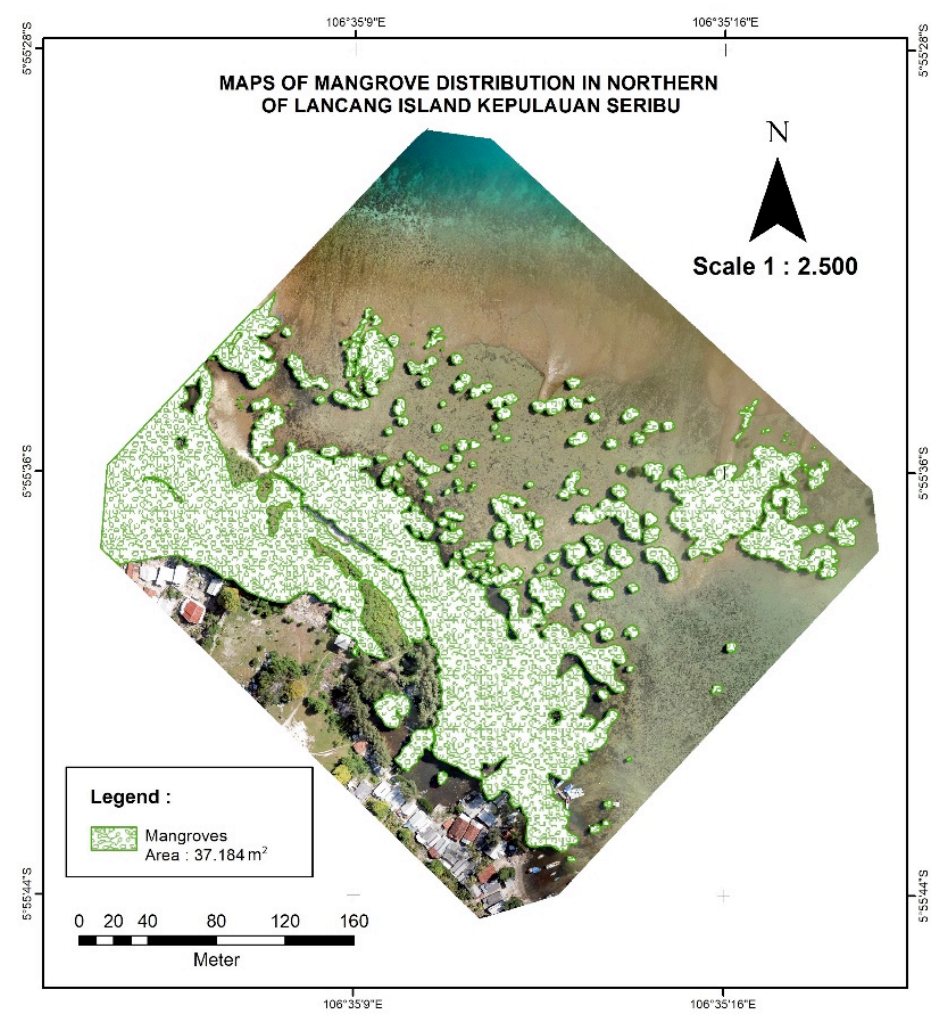

Figure 5 Mangrove Distribution Map

\subsection{Land Cover Classification}

Land cover classification using drone images in the mapping area obtained 7 classes, i.e mangroves, open land, settlements, garbage, graveyard, vegetation and shallow waters.

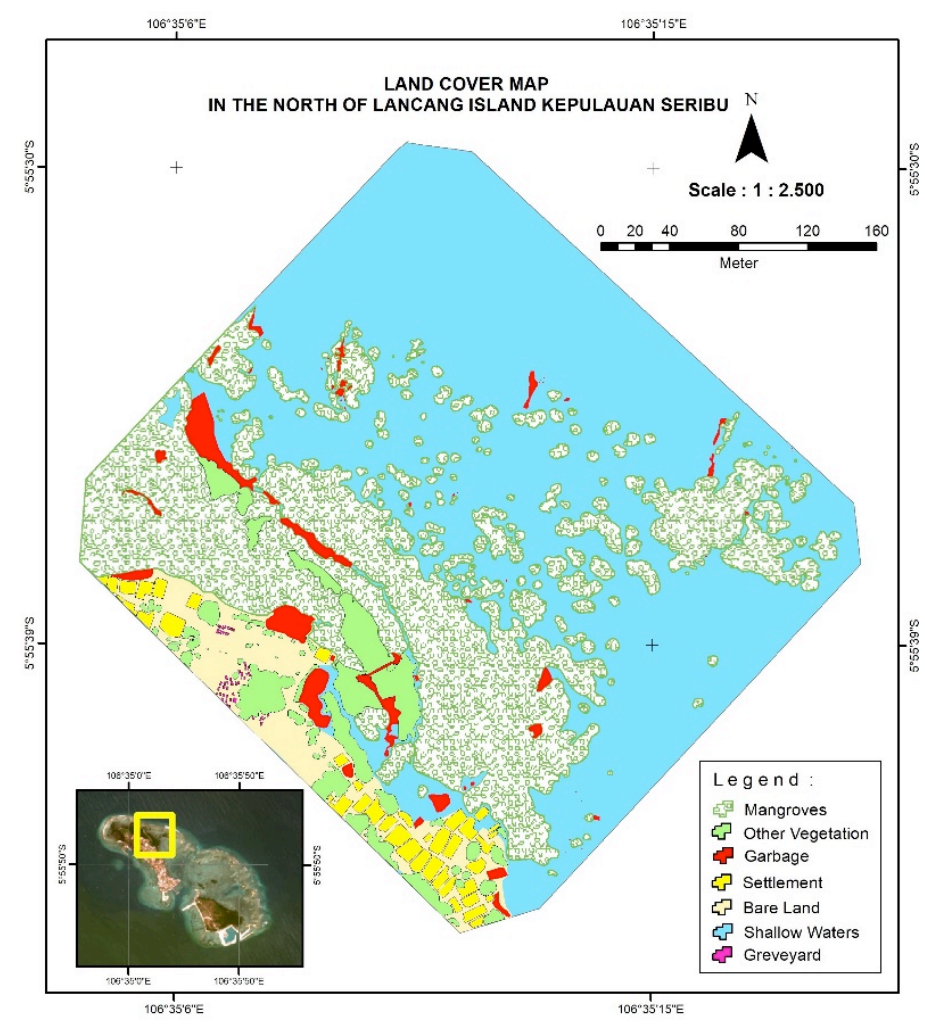

Figure 6 Land Cover Map 
In the map of classification, mangrove land cover is scattered from the environment near settlements and shallow water environments. This finding is in accordance with [18] that stated mangroves are a type of forest vegetation which is dominated by woody plants and inundated by sea water or influenced by tides of sea water, coastal areas with muddy, sandy or sandy mud conditions. Information on the area of land cover can be seen in Table 1 below.

Table 1 Description of land cover area.

\begin{tabular}{clr}
\hline No & Class & Area $\left(\mathrm{m}^{2}\right)$ \\
\hline 1 & Bare Land & 9,320 \\
2 & Mangroves & 37,184 \\
3 & Settlement & 2,535 \\
4 & Shallow waters & 58,572 \\
5 & Garbage & 2,615 \\
6 & Graveyard & 88 \\
7 & Other Vegetation & 5,835 \\
\hline
\end{tabular}

Mangroves have the largest area of the seven classifications, covering 37,184 $\mathrm{m}^{2}$ (about 4 hectares). The graveyard, on the other hand, is the lowest $\left(88 \mathrm{~m}^{2}\right)$. The settlements recorded in the drone photographs were $2,535 \mathrm{~m}^{2}$ and $2,615 \mathrm{~m}^{2}$, which are remarkably similar to the waste area.

\section{Conclussion}

Mapping of mangroves can be done using drones. The integration of mapping using drone technology and supported by field survey activities can produce good mangrove spatial information. This study proves that UAVs can assist in data sampling in mangrove areas and provide spatial distribution and comprehensive area information. However, to identify the type of analysis required further from the data obtained. Species are difficult to determine from the image because the gaps between the tree crowns are not visible. Based on this research, the mangroves on Lancang Island are classified as dense with a mangrove area of $37,184 \mathrm{~m}^{2}$ consisting of Rhizophora mucronata and Rhizophora stylosa.

\section{REFERENCES}

[1] R. Saraswati and R. Abubakar, Perubahan Garis Pantai Pesisir Utara Jawa, no. October. 2020.

[2] T. C. Trinanda, "Pengelolaan Wilayah Pesisir Indonesia dalam Rangka Pembangunan Berbasis Pelestarian Lingkungan," Matra Pembaruan, pp. 75-84, 2017, doi: 10.21787/mp.1.2.2017.75-84.

[3] M. Hidayatullah and E. Pujiono, "Struktur Dan Komposisi Jenis Hutan Mangrove Di Golo Sepang - Kecamatan Boleng Kabupaten Manggarai Barat," J. Penelit. Kehutan. Wallacea, vol. 3, no. 2, p. 151. 2014.

[4] M. Vitasari, "Kerentanan Ekosistem Mangrove terhadap Ancaman Gelombang Ektrim/Abrasi Di Kawasan Konservasi Pulau Dua Banten," Bioedukasi J. Pendidik. Biol., vol. 8, no. 2, p. 33, 2015, doi: 10.20961/bioedukasi-uns.v8i2.3870. 
[5] F. Nugroho and O. I. Al-Sanjary, "A Review of Simulation Urban Growth Model," 2018.

[6] M. Muliady and E. J. Subagya, "Sistem Pemetaan Udara Menggunakan Pesawat Fixed Wing," TESLA J. Tek. Elektro, vol. 21, no. 1, p. 26. 2019.

[7] I. Colomina and P. Molina, "Unmanned aerial systems for photogrammetry and remote sensing: A review," ISPRS J. Photogramm. Remote Sens., vol. 92, pp. 7997. 2014. doi: 10.1016/j.isprsjprs.2014.02.013.

[8] A. Sugara, V. P. Siregar, and S. B. Agus, "Klasifikasi Habitat Bentik Perairan Dangkal Dari Citra Worldview-2 Menggunakan Data in-Situ Dan Drone," J. Ilmu dan Teknol. Kelaut. Trop., vol. 12, no. 1, pp. 135-150. 2020. doi: 10.29244/jitkt.v12i1.26448.

[9] E. Casella et al., "Mapping coral reefs using consumer-grade drones and structure from motion photogrammetry techniques," Coral Reefs, vol. 36, no. 1, pp. 269275. 2017. doi: 10.1007/s00338-016-1522-0.

[10] J. P. Duffy, L. Pratt, K. Anderson, P. E. Land, and J. D. Shutler, "Spatial assessment of intertidal seagrass meadows using optical imaging systems and a lightweight drone," Estuar. Coast. Shelf Sci., vol. 200, pp. 169-180. 2018. doi: 10.1016/j.ecss.2017.11.001.

[11] E. Bevan, S. Whiting, T. Tucker, M. Guinea, A. Raith, and R. Douglas, "Measuring behavioral responses of sea turtles, saltwater crocodiles, and crested terns to drone disturbance to define ethical operating thresholds," PLoS One, vol. 13, no. 3, pp. 117. 2018. doi: 10.1371/journal.pone.0194460.

[12] R. Dahuri, Pengelolaan sumber daya wilayah pesisir dan lautan secara terpadu / oleh H. Rokhmin Dahuri ... [et al.], Cet. 2, Ed. Pradnya Paramita, Jakarta, 2001.

[13] C. E. J. van Bijsterveldt et al., "Does plastic waste kill mangroves? A field experiment to assess the impact of macro plastics on mangrove growth, stress response and survival," Sci. Total Environ., vol. 756, p. 143826. 2021. doi: 10.1016/j.scitotenv.2020.143826.

[14] S. Rahim, W. Widayati, K. Analuddin, F. Saleh, Alfirman, and S. Sahar, "Spatial Distribution of Marine Debris Pollution in Mangrove-Estuaries Ecosystem of Kendari Bay," IOP Conf. Ser. Earth Environ. Sci., vol. 412, no. 1, 2020. doi: 10.1088/1755-1315/412/1/012006.

[15] I. N. N. S. Rusila Noor, Y., M. Khazali, Pengenalan Mangrove di Indonesia, 1999.

[16] C. Kusmana, "Lesson Learned From Mangrove Rehabilitation Program in Indonesia," J. Nat. Resour. Environ. Manag., vol. 7, no. 1, pp. 89-97. 2017. doi: 10.19081/jps1.2017.7.1.89.

[17] Halidah, "The growth of Rhizophora mucronata Lamk at various substrate condition rehabilitation mangrove area in East Sinjai, South Sulawesi," J. Penelit. Hutan dan Konserv. Alam, vol. 7, no. 4, pp. 399-412. 2010.

[18] Onrizal, "Panduan Pengenalan dan Analisis Vegetasi Hutan Mangrove," pp. 1-19, 2008. 